\title{
Mineralization Characterization of Psammitic Rocks in Efon-Alaaye and Environs using Remote Sensing and Field Studies
}

\section{Ayodele Olusiji Samuel ${ }^{1}$ AsubiojoFola Emmanuel ${ }^{2}$}

Department of Applied Geology, The Federal University of Technology, Akure, Nigeria. Email: samuelayodeleolusiji@yahoo.com Tel: +234906041414.2

Email: asubiojofe@futa.edu.ng Tel: +2347069107182

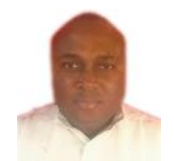

( Corresponding Author)

Abstract

This paper analyses remotely sensed data over a part of the Psammitic Rocks in Efon-Alaaye and Environs to elucidate its geology and structural framework as well as delineate the potential zones of mineralization. The study area belongs to the Precambrian Basement Complex terrain of Southwestern Nigeria and lies within the eastern unit of the Ilesha schist belt. The lithologic units comprise schistose quartzites, quartz schists, quartz-mica-schists, and granitic gneisses. Landsat 8 satellite imagery and Shuttle Radar Topography Mission imagery (SRTM), both of path 190 and row 055, were used for the purpose of this study. A total of 138 lineaments of total length of $147.948 \mathrm{Km}$, were automatically extracted from both data. Rose diagram showed that the lineaments are bi-directional, with major lineaments trending NE-SW, E-W and the subsidiary ones in the NW-SE direction. These lineaments are mostly mapped on the schistose quartzites. Also, N-S trending faults were mapped from the Digital Elevation Model map generated from the SRTM data which was confirmed to be reverse fault based on field studies. The mineral alteration map generated revealed signatures of gold, iron oxides and silica minerals, while the mineralization potential map was done with reference to established geological settings of the area in conjunction with the structural elements such as folds, faults, joints and fractures mapped and measured on the field. These structures are typical of gold mineralization and associated metallic minerals in the Ilesha schist belt. This study also confirmed that mineralization in the study area is structurally controlled and type of mineralization is epigenetic in nature as a result of favorable ground preparation.

Keywords: Efon-Alaaye, Lithologic units, Mineralization, Lineament, Structures, Signature, Imagery.

Citation | Ayodele Olusiji Samuel; AsubiojoFola Emmanuel (2021). Mineralization Characterization of Psammitic Rocks in Efon-Alaaye and Environs using Remote Sensing and Field Studies. Asian Review of Environmental and Earth Sciences, 8(1): 48-61.

\section{History:}

Received: 3 September 202

Revised: 1 October 202

Accepted: 28 October 202

Published: 26 November 202

Licensed: This work is licensed under a Creative Commons

Attribution 3.0 License (oc)

Publisher: Asian Online Journal Publishing Group
Acknowledgement: Both author really appreciates the effort and support of Dr. O. S. Ayodele (Associate Professor, Department of Applied Geology, Federal University of Technology, Akure). Their sincere thanks to the editor and the anonymous reviewer for providing constructive comments on the original manuscript, which significantly enhanced the quality of this work.

Funding: This study received no specific financial support.

Competing Interests: The authors declare that they have no conflict of interests.

Transparency: The authors confirm that the manuscript is an honest, accurate, and transparent account of the study was reported; that no vital features of the study have been omitted; and that any discrepancies from the study as planned have been explained.

Ethical: This study follows all ethical practices during writing.

\section{Contents}

1. Introduction

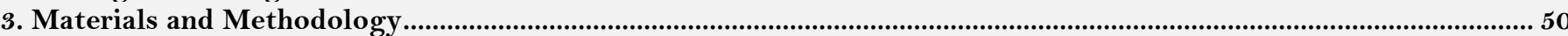

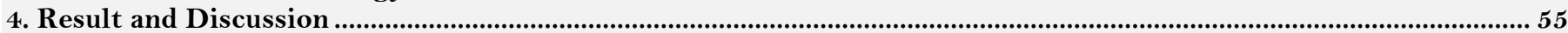

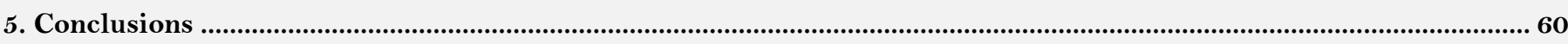

References . 


\section{Contribution of this paper to the literature:}

This paper unravels the geology and structure as well as the mineralization potentials of the psammites in Efon-Alaaye and Environs which is known as the "Efon Psammite Formation". This formation is a combination of several meta-sedimentary sequences of rocks units in the study area by using multi-spectral remote sensing techniques and detailed geo-structural mapping.

\section{Introduction}

The study area belongs to the basement complex terrain of Southwestern Nigeria, and lies within the eastern unit of the Ilesha Schist Belt Figure 1. This unit comprises of the metasedimentary assemblages which includes; quartzite, schists, amphibolites, quartz schist, mica schist. Also the unit comprises of migmatite--quartzite complex which includes; granitic gneiss, banded gneiss, migmatite, quartzo-feldspathic granulite with gneiss [1]. The metasedimentary assemblages has been hitherto referred to as The EffonPsammite Formation [2].

The Northern flanks of the study area Okemesi Figure 1, have been widely investigated by several workers such as $[1] ;[3] ;[4]$. They studied the area using remote sensing methods, in terms of its geology, structures, and mineralization potentials. However, there seems to be paucity of information as regard the nature, geology, structures, and mineralization potentials of the psammites in Efon area.

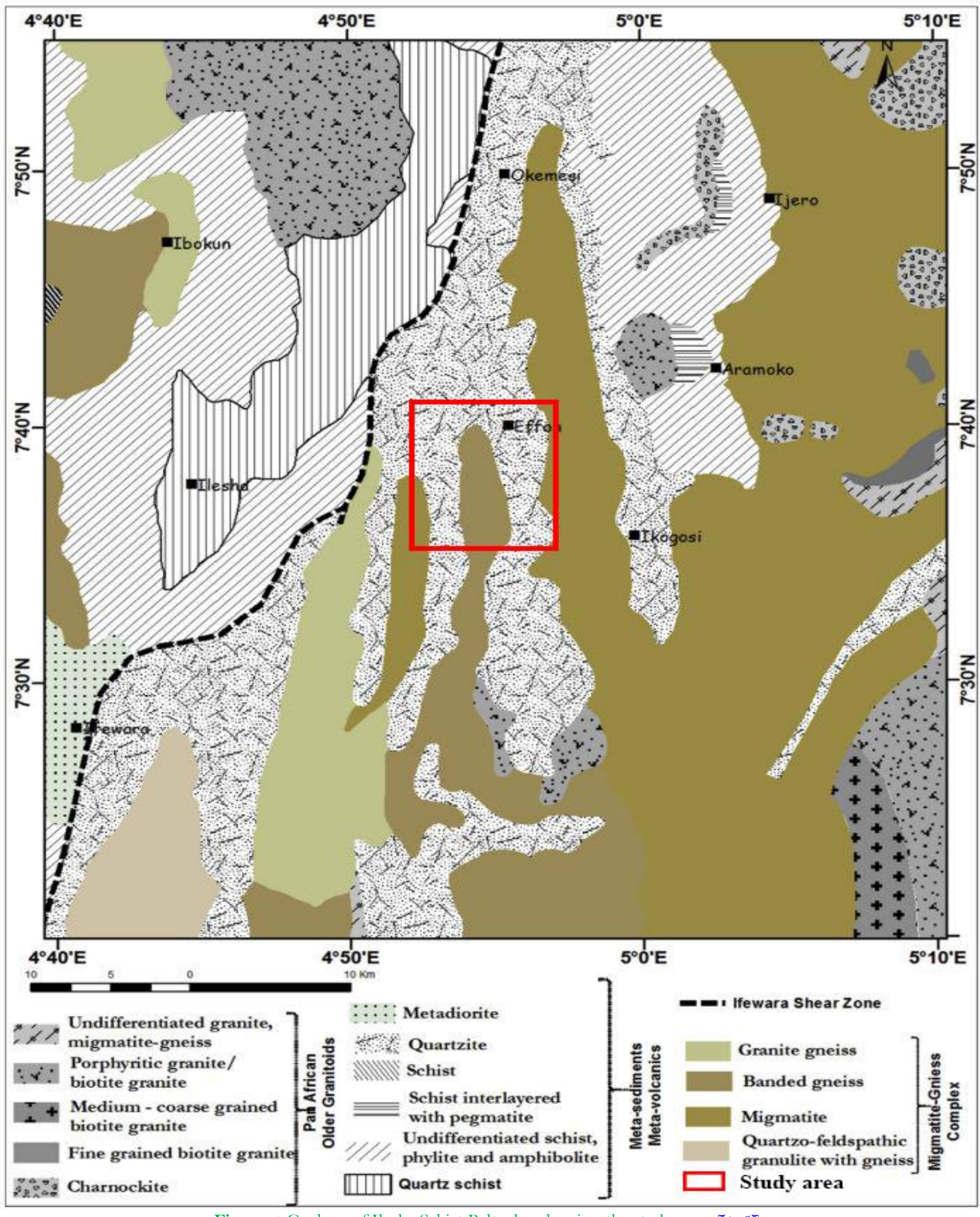

Figure-1.Geology of Ilesha Schist Belt, also showing the study area. [1,5]. 
Remote sensing has been a versatile tool in geology for the understanding of regional mapping, structural interpretation and to aid prospecting of mineral deposits [6]. Understanding the geology and structure of a terrain plays an important role in mineral resource estimation, evaluation and exploration [7-9]. Structural mapping is the identification and characterization of structural expression and these structures includes faults, folds, joints and fractures. Various types of remotely sensed data have been used for geologic mapping such as aerial photographs and satellite derived multispectral images for morphological and lineament mapping [10-12]. In this case, multispectral reflectance data (Landsat 8 Satelite imagery) and shuttle radar topographic mission (SRTM) data were used for the purpose of this research work. Wright, et al. [13] suggested that mineralization in the Ilesha Schist Belt occurs in the form of veins, lenses, stringers, reefs and as quartz-feldspar-tourmaline rocks. While Akande, et al. [14] and Ajayi and Ogedengbe [15] have suggested that gold mineralization occurs in the form of primary and alluvial deposits in the study area. These structures therefore allow the application of the remote sensing method in delineating them in terms of trend, densities and aerial extent [7]. This study is therefore aimed at establishing the geology and delineating geological structures that could host mineralization in the area using remote sensing method.

\section{Geological Setting}

The study area Figure 2 is situated in Efon Local Government Area of Ekiti State and part of Osun State South-West Nigeria, with an approximated area of $100 \mathrm{~km}^{2}$, it can be located within longitudes $4^{\circ} 52^{\prime} 0^{\prime \prime} \mathrm{E}$ and $4^{\circ} 57^{\prime \prime}$ $\mathrm{O}^{\prime} \mathrm{E}$, latitudes $7^{\circ} 35^{\prime} \mathrm{O}^{\mathrm{N}} \mathrm{N}$ and $7^{\circ} 41^{\prime} \mathrm{O}^{\prime \prime} \mathrm{N}$. It is dominated by prominent north-south trending ridges, separated by relatively lowland Figure 3. This is an indication of an active area of orogeny and other geological processes [16], hence the ridges are structural markers that delineate folds and lineaments. The study area also belongs to the Basement Complex terrain of Southwestern Nigeria and lies within the eastern unit of the Ilesha Schist Belt. The lithologic units comprises schistose quartzite, quartz schist, mica-quartz-schist with subordinate granitic gneiss Figure 4 [16-18]. However, the schistose quartzites in the study area are pelitic because they are metamorphosed from sandstone and tend to form good topographic features [16]. The schistose quartzite occupies about $50 \%$ of the entire study area occupying the central part Figure 5. The texture of the rocks range from medium-fine grained and the colors vary from purple, brown, yellow to milky. They also display joints of different magnitudes and orientations and several joint sets trending NE-SW, E-W and NW-SE [17, 19]. The quartz schists which is formed at the base of the schistose quartzite ridge occur as low-lying outcrops. It exhibits strong foliation with its strike orientating generally to the north and steeply dipping to the east and west. The quartz-mica-schist is generally low-lying and steeply dipping to the west. The granitic gneiss which is a highly resistive rock in the area has mineralogical banding of felsic minerals such as quartz and feldspar with streaks of biotite. It has a medium to coarse-grained texture and possessing moderate to strong foliation [18]. Generally, the rock of the study area has been subjected to at least two deformational episodes $[18,20]$. The early deformation includes regional metamorphism in the area, causing the rocks to trend N-S, and also the formation of mega folds (synformantiformassymetrical and overturned fold) Figure 4. The recent deformation episode gave rise to fracturing and faulting of the rocks $[1,16,21,22]$.

\section{Materials and Methodology}

Landsat 8 satellite imagery Figure 5 and SRTM imagery Figure 6. Both of path 190 and row 055, were downloaded from USGS website (www. usgs.gov), for the purpose of this study. The automatic lineament extraction process was carried out with LINE module of PCI Geomatica 2015 software, based on automatic detection algorithms (canny algorithms). The ArcGIS 10.3 software was used to digitize the lineaments, produce the density map, Digital Elevation Model (DEM) map, and mineral alteration map. While RockWorks 17 software was used to produce the lineament rose diagram. Firstly the Landsat 8 data was uploaded to the ArcGIS 10.3 software and Principal Component Analyses (PCA) was carried out to get the best imagery suitable for the extraction of lineaments. This imagery and the SRTM imagery were then exported to PCI Geomatica 2015 software, where the lineaments were automatically extracted. The lineaments extracted were exported as shapefile into the ArcGIS 10.3 for the production of the lineament density. The lineament density of the area was computed using the Line Density tool within ArcGIS 10.3. It is expressed in $\mathrm{Km}^{2}$. Rose diagram of the lineaments was generated using the Rockworks 17 software. This was done after the lineaments extracted was exported into the ArcGIS 10.3 environment where it was prepared by creating X_start, X_end, Y_start, Y_end, X-mid and Y_mid coordinate using the Calculate Geometry tool and exported in CAD format. The rose diagram was finally generated in Rockworks 17 software and exported as a jpeg image. Proper band combinations for minerals were factored in using ArcGIS 10.3 software to produce the mineral alteration map of the study area It was discovered that band $2,4,5,6$, and 7 are the most suitable for the minerals present within the study area. The Digital Elevation Model map was generated from the processing of the SRTM imagery over the study area in the ArcGis environment. 


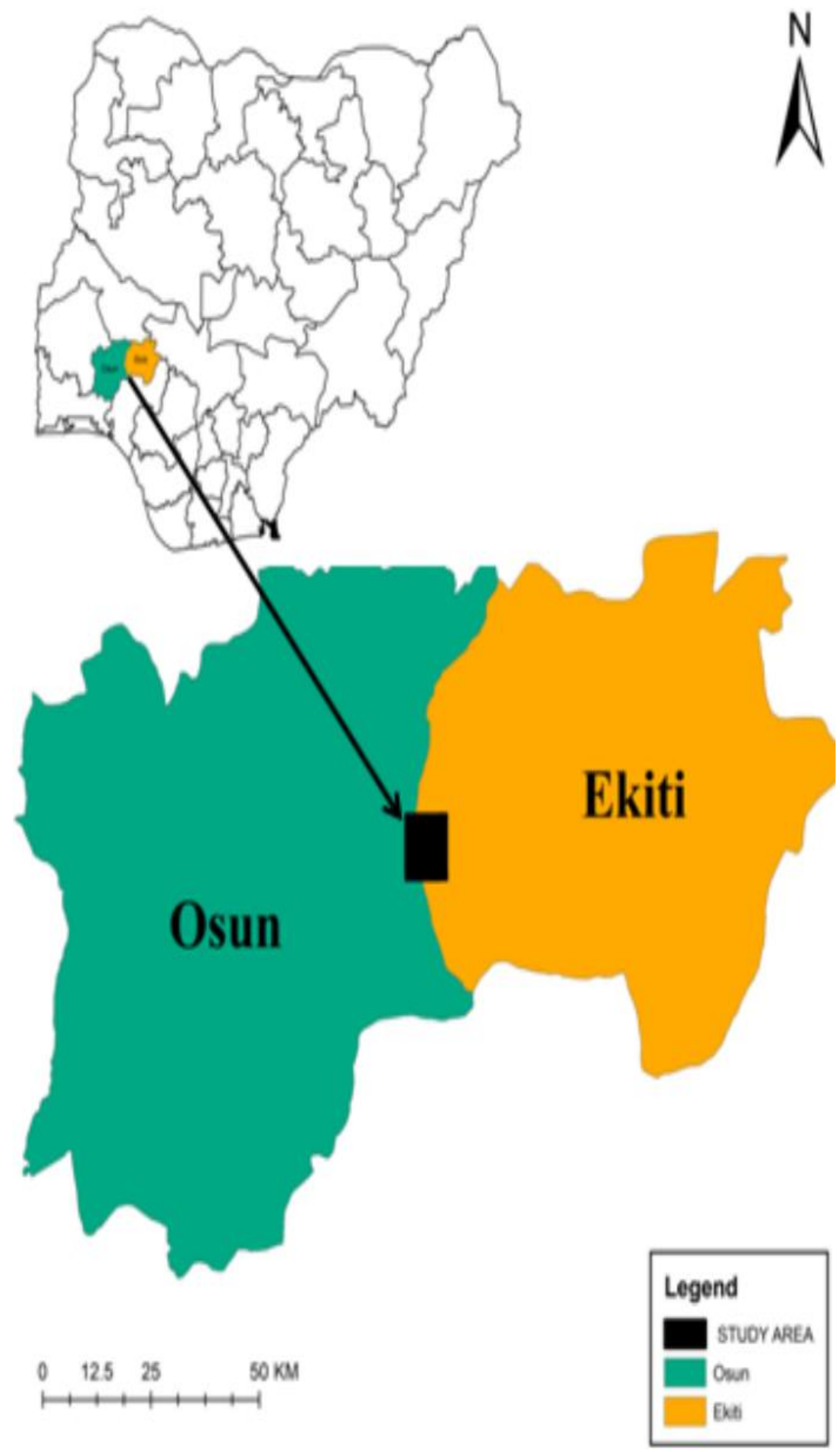

Figure-2. Map of the study area located within Ekiti and Osun States inset: Map of Nigeria showing the study area. 


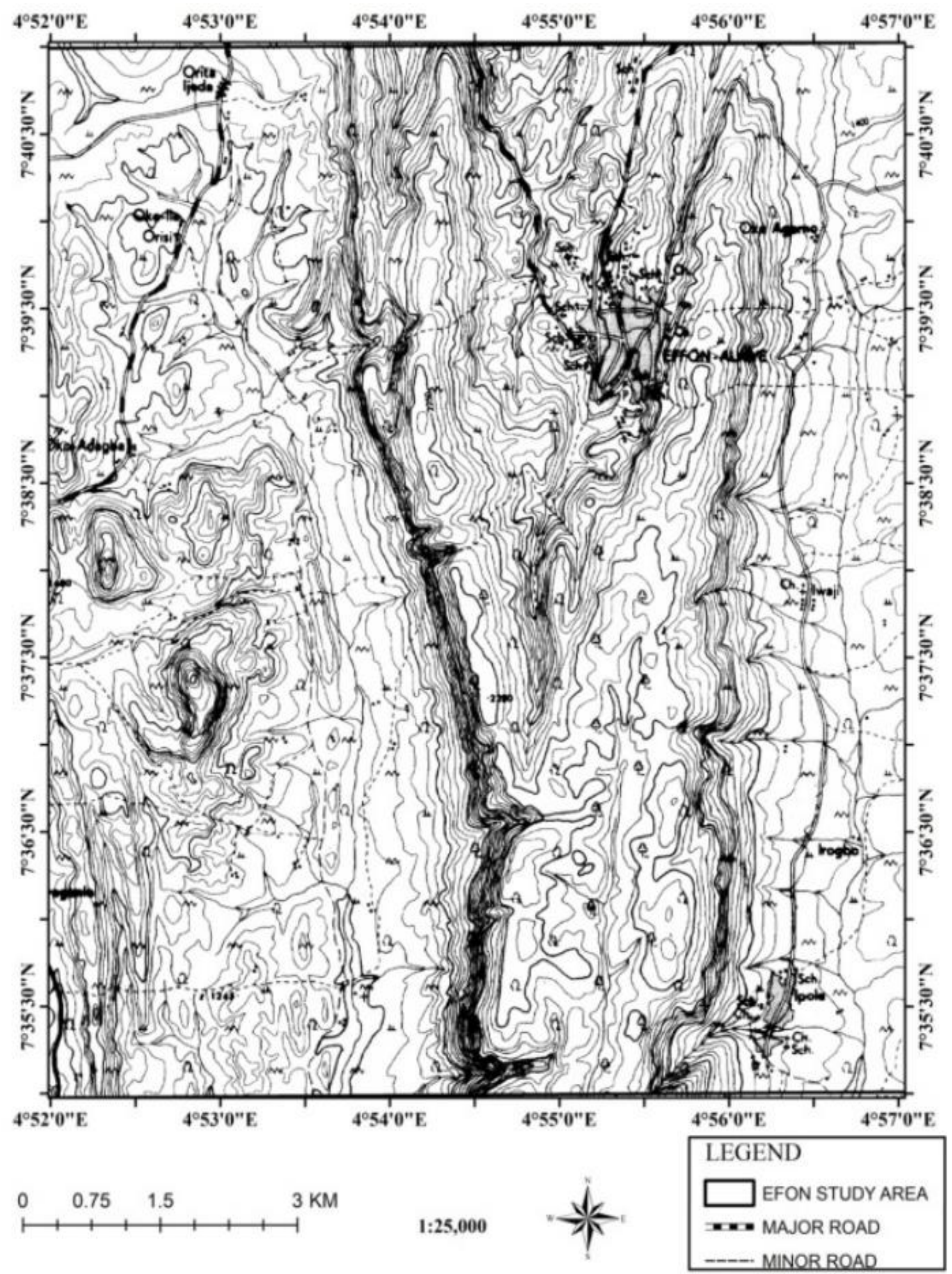



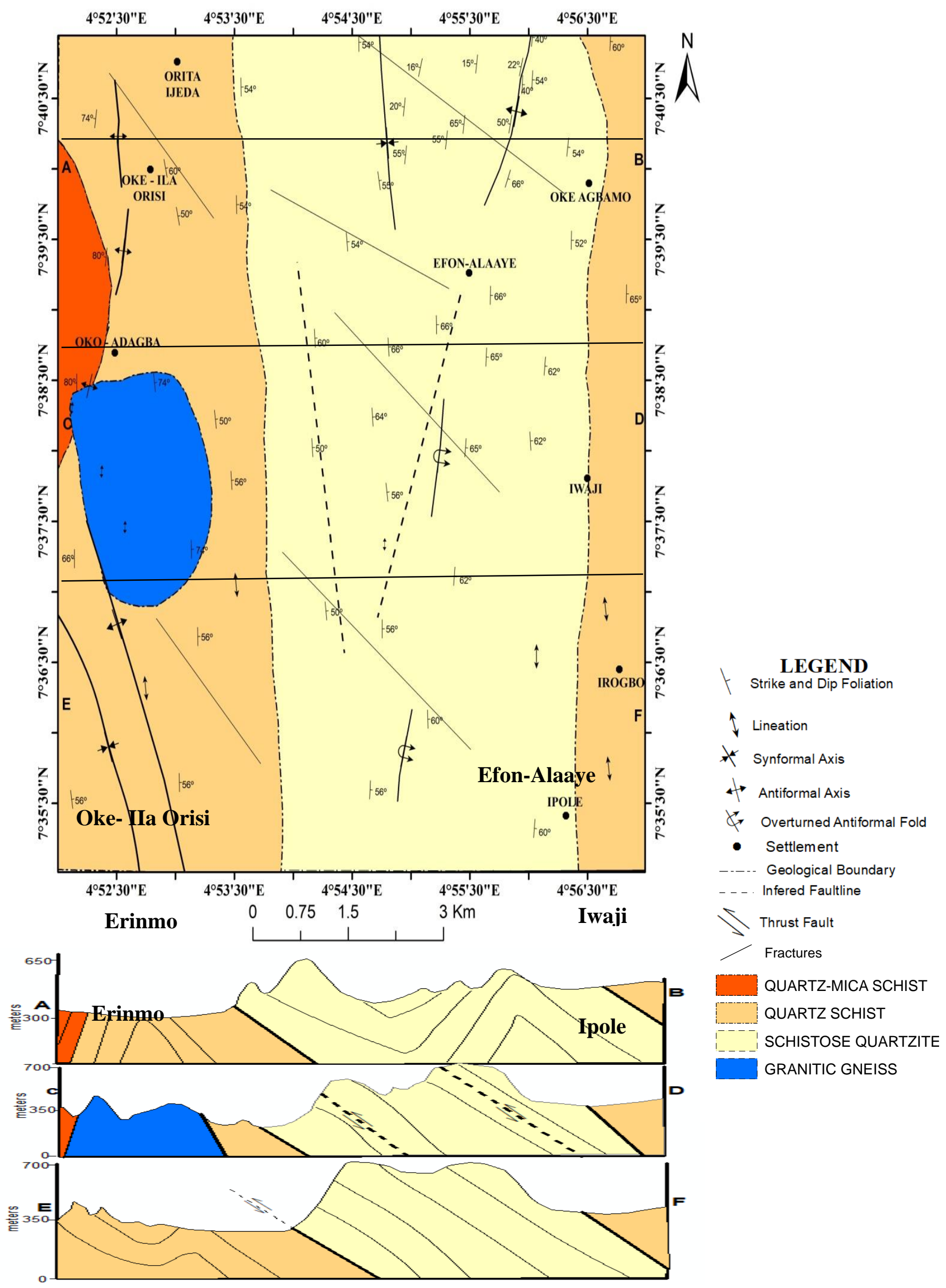

LEGEND

Strike and Dip Foliation

$\uparrow$ Lineation

Synformal Axis

$\leftrightarrow$ Antiformal Axis

Overturned Antiformal Fold

- Settlement

Geological Boundary

Infered Faultline

Thrust Fault

Fractures

QUARTZ-MICA SCHIST QUARTZ SCHIST SCHISTOSE QUARTZITE GRANITIC GNEISS

Figure-4. Structural Geological Map and cross section of the Study area. 


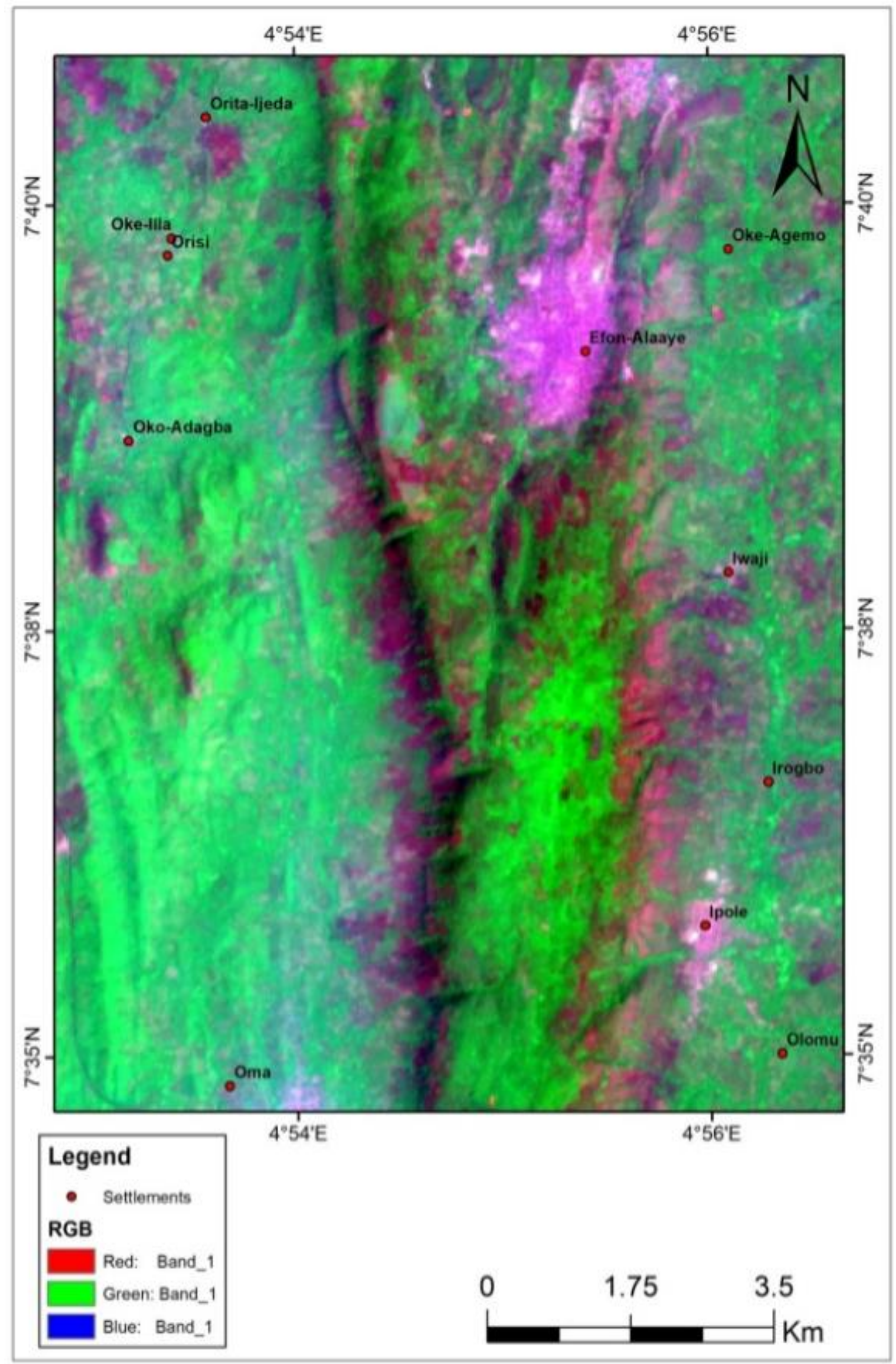

Figure-5. Landsat 8 imagery of the Study area (www. usgs.gov). 


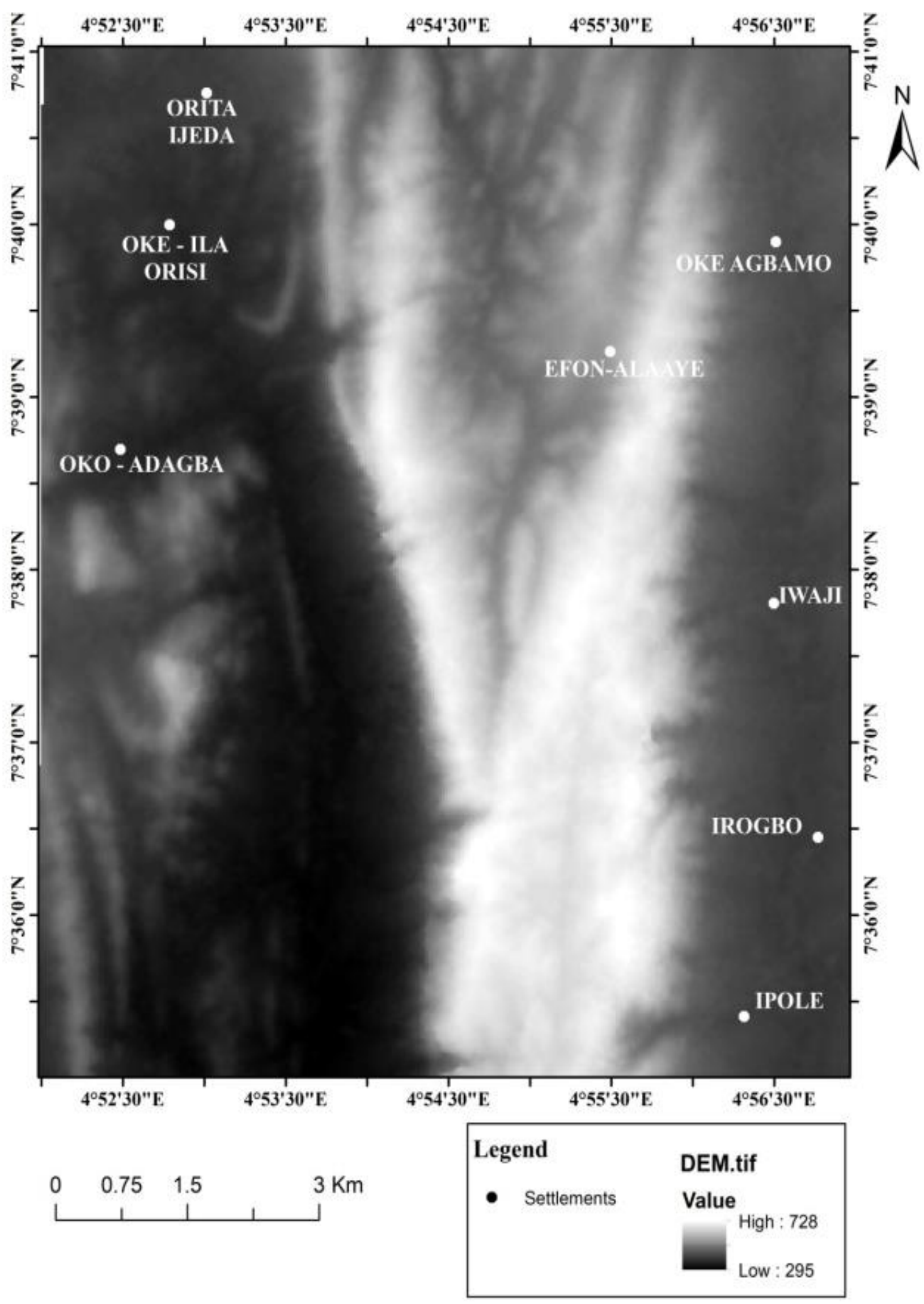

Figure-6. SRTM imagery of the Study area (www. usgs.gov).

\section{Result and Discussion}

\subsection{Lineament Map}

The lineament map superimposed on the geological map of the study area is presented in Figure 7. The major trends of the lineaments are in the NE-SW, E-W directions, with the subsidiary ones trending NW-SE direction. Schistose quartzite are the most and highly fractured rock in the study area with the fracture mostly trending NESW direction, followed by the quartz schist. The granitic gneiss and the quartz-mica-schist show little fracturing because of their ductile behaviour. The highly fractured nature of the schistose quartzite is because the rock is very brittle in nature, highly brittle than the quartz schist, granitic gneiss and the quartz-mica-schist. The response of these rocks to deformation is dependent on their mineral compositions, temperature, pressure and depth. 


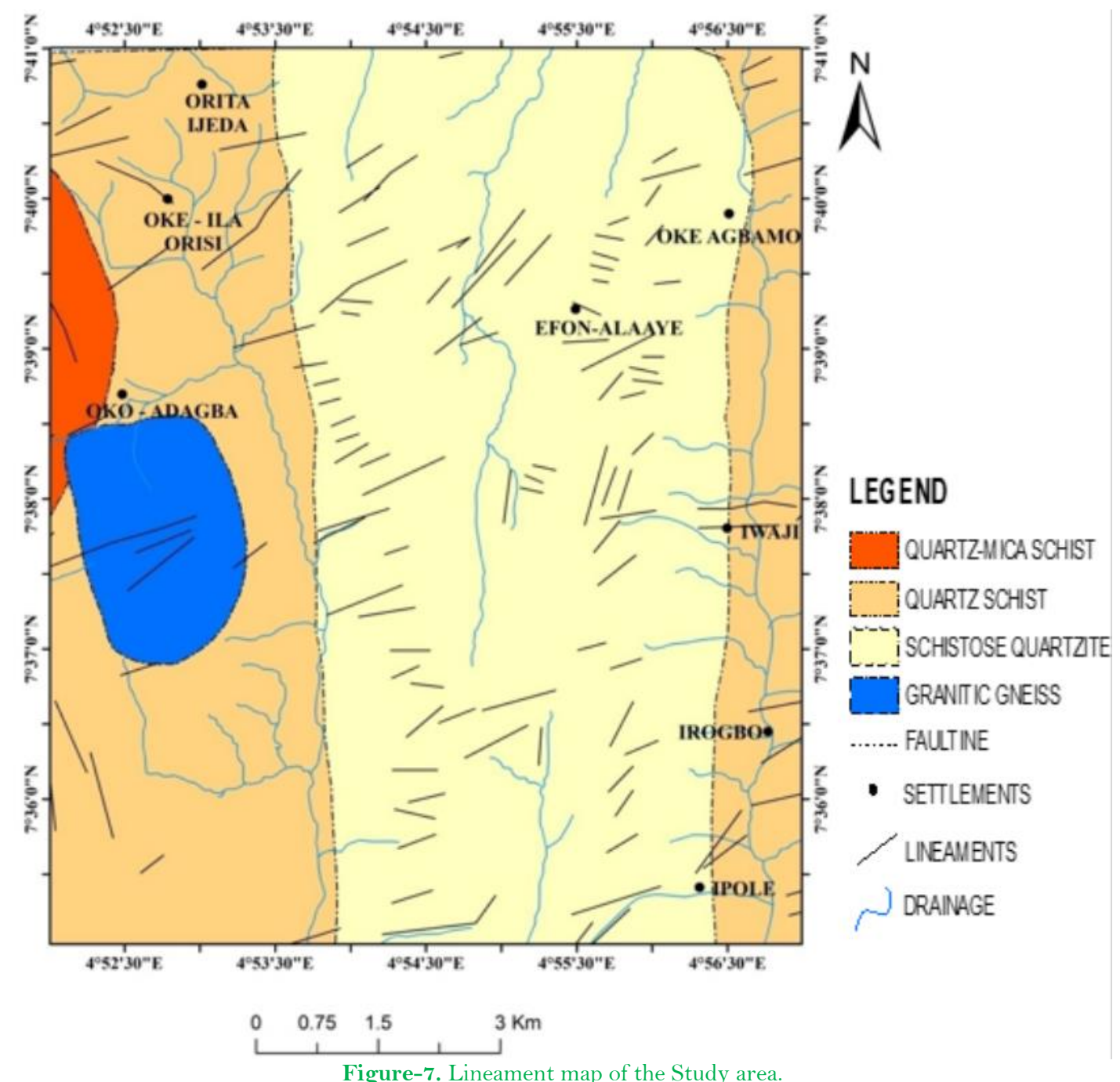

\subsection{Rose Diagram}

The rose diagram generated for the lineaments is presented in Figure 8. A total of 138 lineaments were mapped from the remote sensing data. The total length of the lineaments are $147.948 .08 \mathrm{Km}$. The rose diagram shows that the linear structures in the study area are bi-directional, which indicated major fractures are in the NESW, E-W, and the subsidiary ones in NW-SE directions.

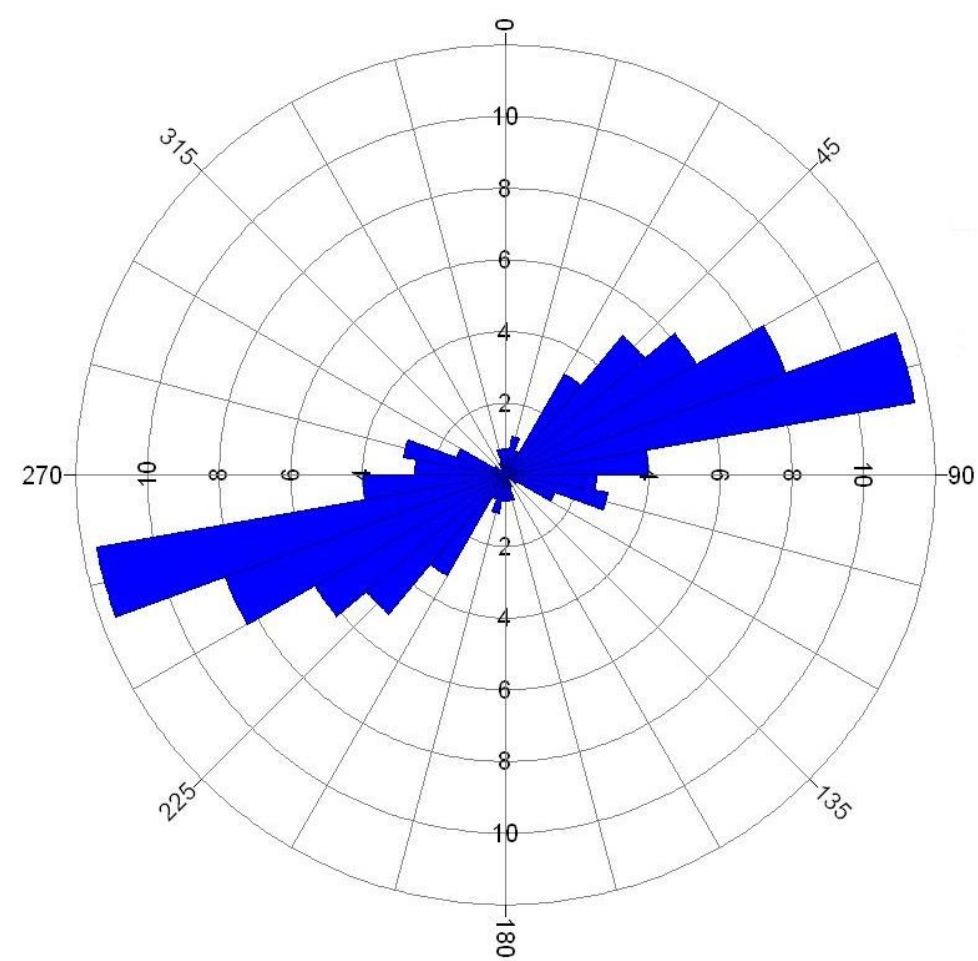

Figure-8. Rose diagram generated from the lineament map.

\subsection{Lineament Density Map}

The lineament density map of the study area is presented in Figure 9. The map revealed that higher fracture densities occur mostly on the schistose quartzite. This can be attributed to the brittle and shearing nature of the rock caused by the thermos-tectonic influence of the Ifewara mega shear, while there is paucity of fractures on the 
granite gneiss. Ramesh, et al. [7] established that mineralization are usually associated with areas of high density fractures; hence the schistose quartzite units in the Efon area are likely to host mineralization.

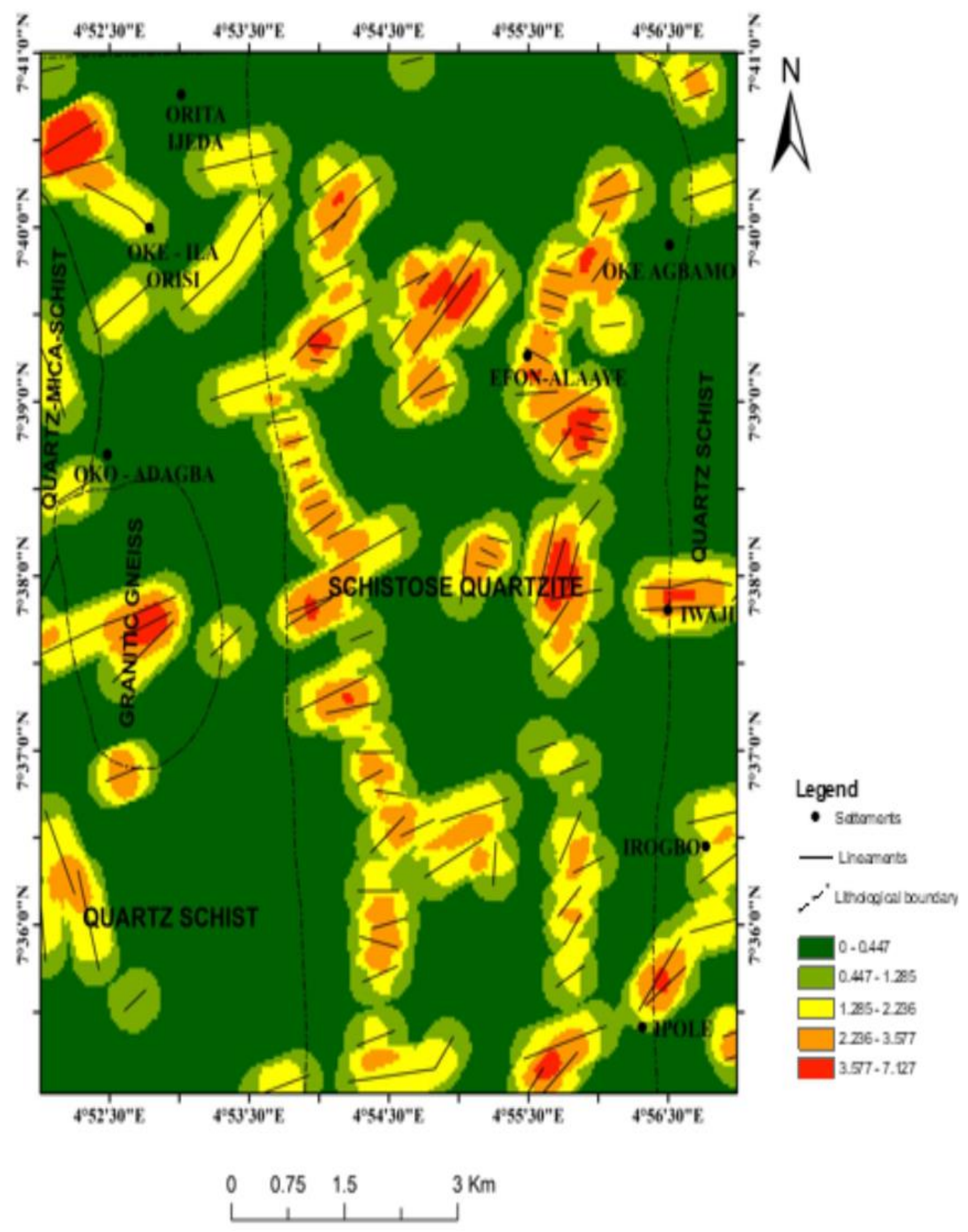

4.4. Mineral Alteration Map

The mineral alteration map is presented in Figure 10. Band rationing method was used to map out area that shows signatures of gold, iron oxides, base metals and silica minerals in the study area. From the mineral alteration map, signature of gold, iron oxides and silica mineral are widespread and majorly seen on the highly fractured schistose quartzite rock; the gold signature becomes more evident around the schistose quartzite located within the Efon town, while the signatures of Iron oxide are evident on the quartz schist, granitic gneiss and quartz-micaschist. This is an indication of gemstone mineralization. The base metals signatures are scarcely distributed throughout the entire study area. 


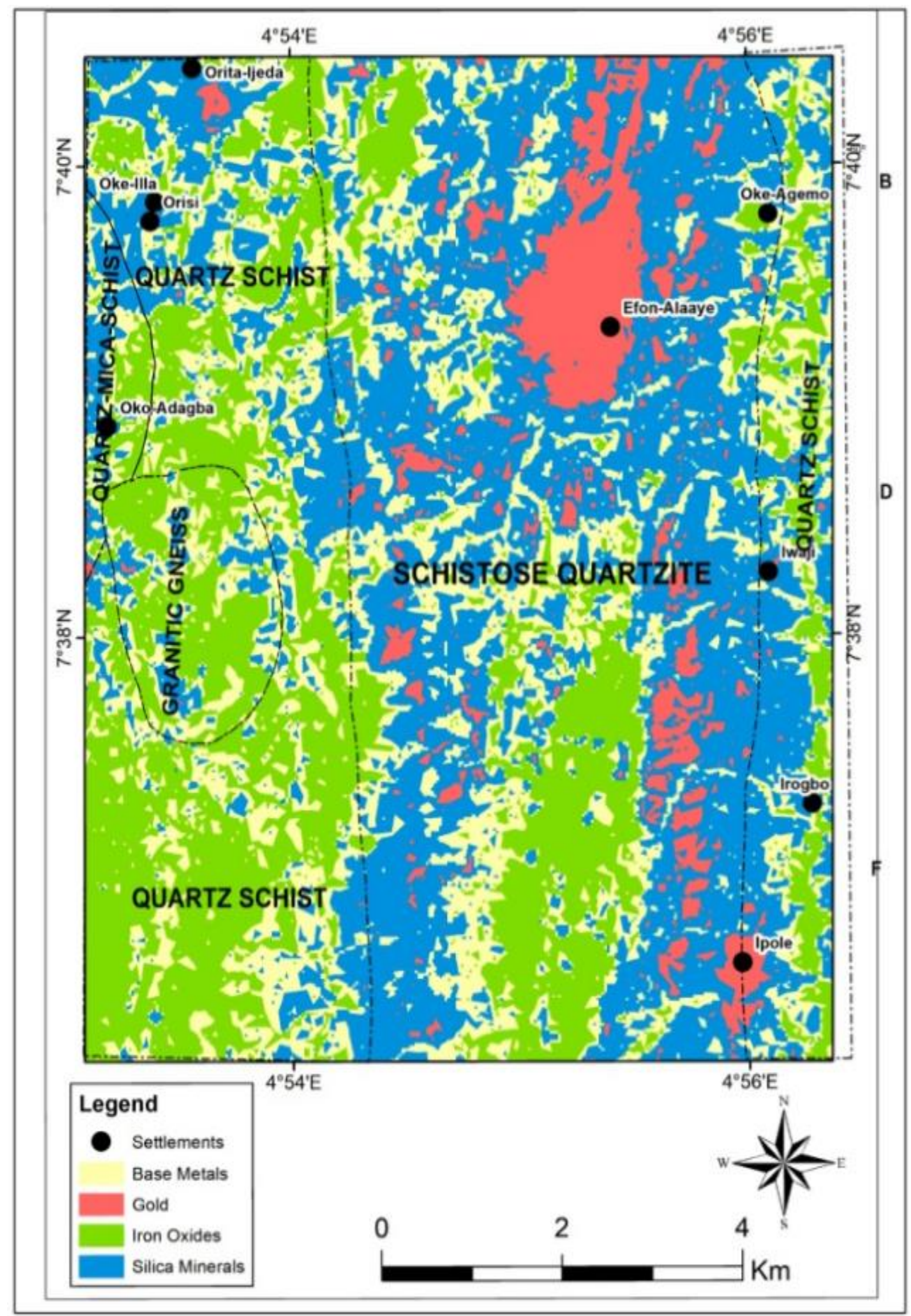

Figure-10. Mineral Alteration map of the study area.

\subsection{Digital Elevation Map}

The Digital Elevation Map (DEM) of the study area is presented in Figure 11. This map shows that the schistose quartzite are generally high in elevation and ranges from $445 \mathrm{~m}$ to $728 \mathrm{~m}$, while the quartz schist and the quartz-mica-schist are generally low-lying ranging from $295 \mathrm{~m}$ to $444 \mathrm{~m}$, while the granitic gneiss appears to have moderate elevation ranging $379 \mathrm{~m}$ to $616 \mathrm{~m}$. A likely fault was detected from the DEM map of the study area Figure 11 and also from visual inspection of the Landsat 8 imagery Figure 5. The sharp contrast between the lowest elevation of the quartz schist and highest elevation of the schistose quartzite is suspected to be a reverse fault. This is similar to faults established by Odeyemi [1] and Anifowose, et al. [22] in the Ilesha schist belt, they reported that these faults are associated with the Ifewara Fault and are indicative of possible subduction zone in an oceanic basin. Also from the DEM interpretation, it can be observed that there is a possibility that the rocks of the entire study area has been folded and refolded. 

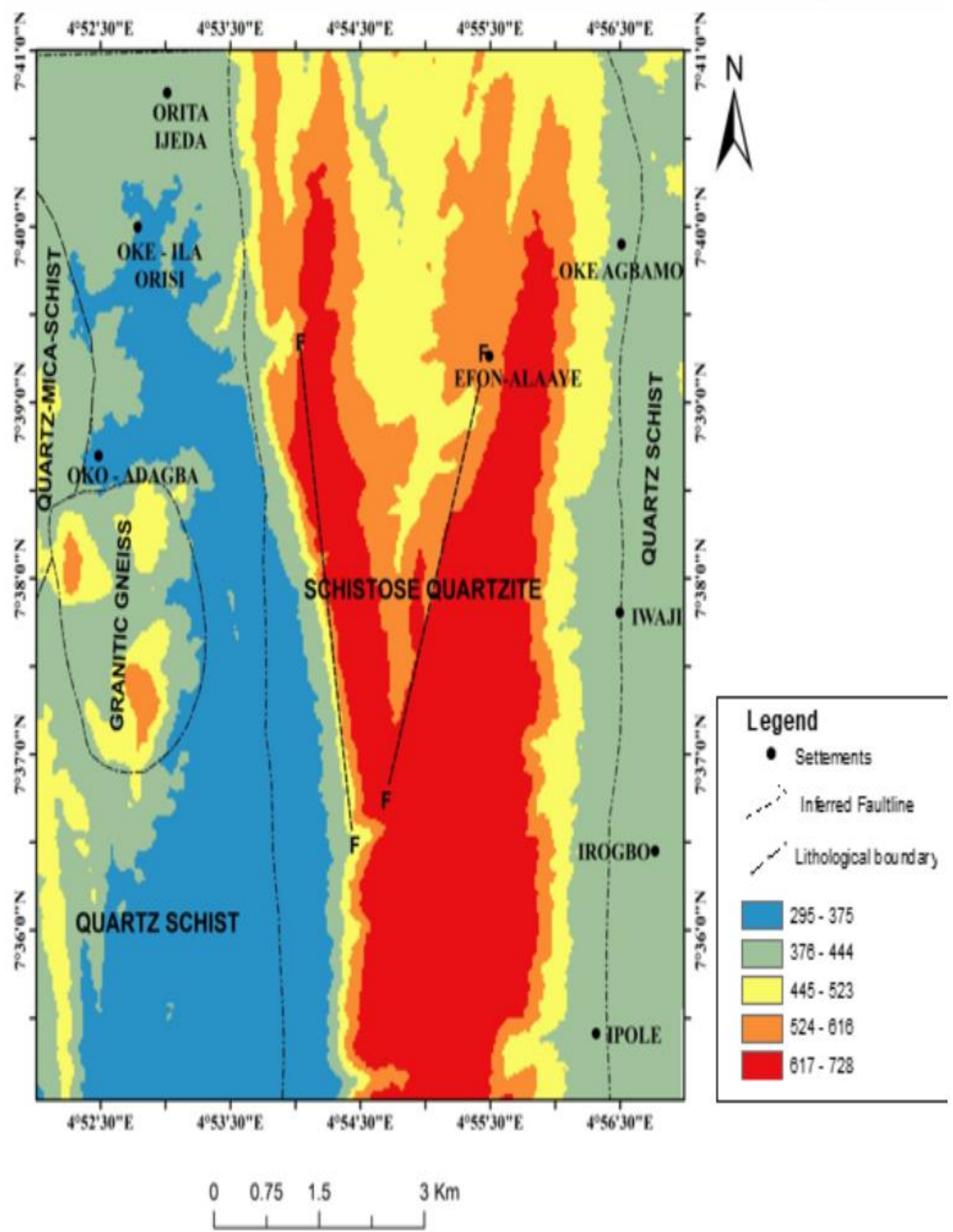

Figure-11. Digital elevation map (DEM) map of the study area.

4.6. Mineralization Potential Map

Figure 12 shows the mineralization potential map of Efon area of the Ilesha schist belt from the lineament map, lineament density map, mineral alteration map, and Digital Elevation Model (DEM) map. Areas, where the delineated structures on the lineament map coincide with structures on the DEM map and mineral signatures on the mineral alteration map are typical of mineralized zones. The mineralization map also reveals potential zones where ore deposits can be assessed such as around Efon-Alaaye, Erinmo and Ipole Figure 12. The structural pattern revealed that considerable mineralisation within the area lies predominantly along NE-SW direction and rarely along W-E trending structures and along the N-S trending fault. The overlay of the mineralisation map with the geologic map of area suggests that mineralisation is associated more with the schistose quartzite and contact between rocks. 


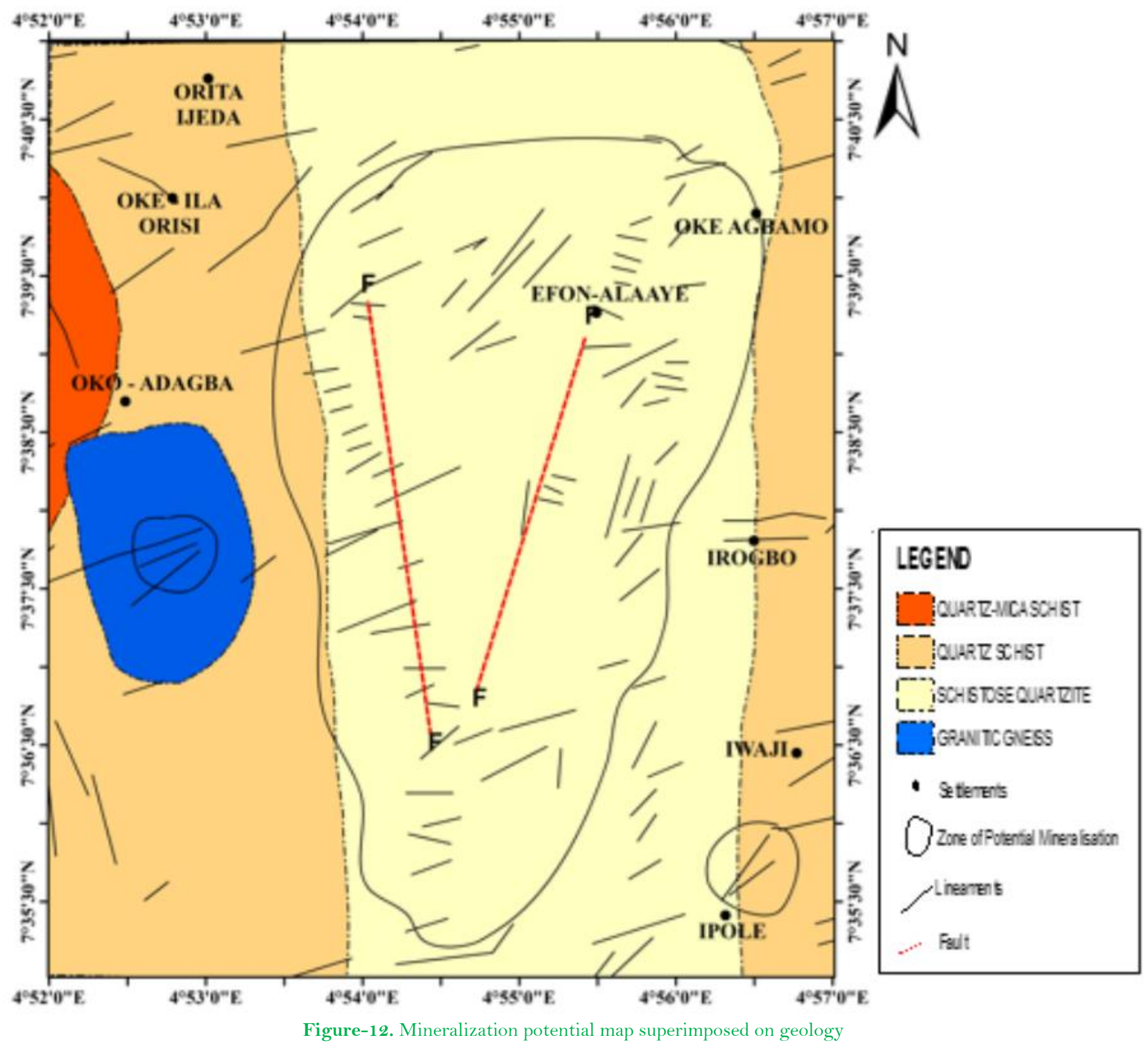

\section{Conclusions}

The study area is underlain by schistose quartzites, quartz schists, quartz-mica-schists and granitic gneisses. This study revealed that the schistose quartzites rocks are the most fractured rock, it has more lineaments densities and the lineaments are trending NE-SW, E-W and NW-SE. These lineaments are similar to structures that are associated to the Pan-African deformation to host mineralization in the Ilesha schist. Mineralization is observed to be distributed mainly on schistose quartzite unit. Signatures of gold, iron oxide, silica mineral are wide spread on the schistose quartzite; this is an indication of metallic and gemstone mineralization. Generally the area has been faulted and folded resulting from two deformational episodes.

\section{References}

[1] I. B. Odeyemi, "A comparative study of remote sensing images of the structure of the Okemesi Fold Belt, Nigeria," ITC Journal, vol. 1931-1, pp. 77-81, 1993.

[2] F. H. Hubbard, "Precambrian crustal development in western Nigeria: Indications from the Iwo region," Geological Society of America Bulletin, vol. 86, pp. 548-554, 1975.

[3] A. Anifowose and A. Borode, "A photogeological study of the fold structure in okemesi area, Nigeria," Journal of Mining and Geology, vol. 43, pp. 125-130, 2007.

[4] O. S. Ayodele, "Remote sensing and geological study of Oke-mesi Area S.W Nigeria," African Journal of Science Technology Innovation and Development, vol. 1, pp. 134-137, 2010.

[5] Nigeria Geological Survey Agency, "Geological map of Ilesha Schist Belt," 2006.

[6] F. D. Van der Meer, H. M. Van der Werff, F. J. Van Ruitenbeek, C. A. Hecker, W. H. Bakker, M. F. Noomen, M. Van Der Meijde, E. J. M. Carranza, J. B. De Smeth, and T. Woldai, "Multi-and hyperspectral geologic remote sensing: A review," International Journal of Applied Earth Observation and Geoinformation, vol. 14, pp. 112-128, 2012.

[7] C. P. Ramesh, P , T. Jayaram, and G. Jayalakshmi, "An analysis of lineaments and mineral occurrences of Veligallu Schist Belt and surroundings, Eastern Dharwar Craton, India using Remote Sensing \& GIS," Journal of Multidisciplinary Engineering Science and Technology (JMEST), vol. 1, pp. 198-204, 2014.

[8] D. B. Waele, M. Lacorde, M. Cunningham, and B. Jupp, "Understanding geology and structure: An essential part of mineral resource estimation," ASEG Extended Abstracts, vol. 2018, pp. 1-8, 2018.Available at: https://doi.org/10.1071/aseg2018abm2_2f.

[9] J. d. A. Uwiduhaye, J. C. Ngaruye, and H. Saibi, "Defining potential mineral exploration targets from the interpretation of aeromagnetic data in western Rwanda," Ore Geology Reviews, p. 103927, 2020.

[10] J. Wang and P. J. Howarth, "Use of the hough transform in automated lineament," IEEE Transactions on Geoscience and Remote Sensing, vol. 28, pp. 561-567, 1990.Available at: https://doi.org/10.1 109/tgrs.1990.572949.

[11] K. Koike, S. Nagano, and M. Ohmi, "Lineament analysis of satellite images using a Segment Tracing Algorithm (STA)," Computers E Geosciences, vol. 21, pp. 1091-1104, 1995.Available at: https://doi.org/10.1016/0098-3004(95)00042-7. 
[12] A. Karnieli, A. Meisels, L. Fisher, and Y. Arkin, "Geological linear features from digital remote sensing data using a Hough transform," Photogramm. Eng. Remote Sens, vol. 62, pp. 525-531, 1996.

[13] J. B. Wright, D. A. Hastlings, W. B. Jones, and H. R. Williams, Geology and mineral resources of West Africa. London: George Allen and Unman, 1985

[14] S. O. Akande, A. Hoffknecht, and B. D. Erdtmann, "Rank and petrographic composition of selected Upper Cretaceous and Tertiary coals of southern Nigeria," International Journal of Coal Geology, vol. 20, pp. 209-224, 1992.

[15] T. Ajayi and O. Ogedengbe, "Opportunity for the exploitation of precious and rare metals in Nigeria," Prospects for Investment in Mineral Resources of southwestern Nigeria,(ed.) AA Elueze, vol. 1526, pp. 15-26, 2003.

[16] O. S. Ayodele, "Litho-geochemical and petrogenetic characteristics of some massive and schistose quartzites in Ekiti State, Southwestern Nigeria," International Journal of Science Inventions Today, vol. 3, pp. 013-040, 2014.

[17] O. Okunlola, O. Adeigbe, and O. Oluwatoke, "Compositional and petrogenetic features of schistose rocks of Ibadan Area, Southwestern Nigeria," Earth Sciences Research Journal, vol. 13, pp. 119-133, 2009.

[18] B. Adeoti and C. T. Okonkwo, "Structural geology of the basement complex rocks in Iwaraja area, Southwestern Nigeria," International Letters of Natural Sciences, vol. 58, pp. 16-28, 2016.Available at: https://doi.org/10.18052/www.scipress.com/ilns.58.16.

[19] A. Akinlalu, A. Adelusi, G. Olayanju, K. Adiat, G. Omosuyi, A. Anifowose, and B. Akeredolu, "Aeromagnetic mapping of basement structures and mineralisation characterisation of Ilesa Schist Belt, Southwestern Nigeria," Journal of African Earth Sciences, vol. 138, pp. 383-391, 2018.Available at: https://doi.org/10.1016/j.jafrearsci.2017.11.033.

[20] M. O. Oyawoye, "The basement complex of Nigeria, In: Dessauvagie, T.F.J. and Whiteman, A.J., Eds., African Geology," ed Ibadan: University of Ibadan Press, 1972, pp. 67-99.

[21] A. Gandu, S. Ojo, and D. Ajakaiye, "A gravity study of the Precambrian rocks in the Malumfashi area of Kaduna State, Nigeria," Tectonophysics, vol. 126, pp. 181-194, 1986.Available at: https://doi.org/10.1016/0040-1951(86)90227-1.

[22] A. Y. B. Anifowose, I. B. Odeyemi, and A. M. Borode, "The tectonic significance of the Ifewara-Zungeru Megastructure in Nigeria," in Proceedings of the 1st International Workshop on Geodesy and Geodynamics, Centre for Geodesy and Geodynamics, Toro, Bauchi State, Nigeria, 2006, pp. 17-28.

[23] FSN, "Topographic map series :Ilesha Sheet 243 (SW \& SE). Scale 1:50,000," 1966. 